\title{
PREVALENCE AND SUSCEPTIBILITY PATTERN OF ANAEROBIC BACTERIA ISOLATED FROM WOUND SWABS IN CLINICAL CENTRE UNIVERSITY OF SARAJEVO
}

\author{
Đana Granov ${ }^{1,3}$, Daria Bekić1, El-Jesah Đulić́, Amela Dedeić-Ljubović' ${ }^{1,2,3}$
}

(C) 2019 by Acta Medica Saliniana ISSN 0350-364X

DOI: $10.5457 / 523$

Đana Granov

Daria Bekićı

El-Jesah Đulić

Amela Dedeić-Ljubović

\footnotetext{
Afiliations:

${ }^{1}$ Clinical Centre University of

Sarajevo, Bosnia and Herzegovina,

${ }^{2}$ University of Sarajevo, Faculty of

Health Studies,

${ }^{3}$ University Sarajevo, School of

Science and Technology, Sarajevo

Medical School, 71 ooo Sarajevo,

Bosnia and Herzegovina
}

Corresponding author:

Djana Granov

djana.granov@ssst.edu.ba

\begin{abstract}
Objectives: Anaerobic bacteria may cause numerous infections in different locations through human body. Those infections can be life-threatening with significant mortality. Wounds represent a suitable habitat for colonization of anaerobic bacteria. Their proliferation contributes to moist and warm environment, hypoxic and necrotic tissue.

Methods: A retrospective study was conducted at the Clinical Centre University of Sarajevo from 2015-2017. The study involved wound swab samples, sampled from hospitalized patients. The anaerobic bacteria were isolated using standard procedures. Results: During the period from 01.01.2015. to 31.12.2017, 8386 samples were analyzed on anaerobic bacteria and $872(10.4 \%)$ of specimen were positive. In 2015, $332(15 \%)$ specimens were positive, while during 2016 and 2017, 244 (7,8\%) and 296 (9.9\%) respectively. Bacteroides spp. was the most common isolate during three year period: 2015-227 (55.5\%); 2016-139 (48\%); 2017-161 (42,5\%). It was followed by Peptococcus spp.: 2015-70 (17.1\%); 2016-40 (13.9\%); 2017-66 (17.4\%), Clostridium spp.: 2015 - 32 (7.8\%); 2016-21 (7.3\%); 2017- 35 (9.2\%), Fusobacterium spp.: 2015 - 49 (11.9\%); 2016-32 (11.1\%); 2017- $45(11.9 \%)$.

VITEK 2 Compact has identified to the level of species 48 isolates which were in pure culture.

The largest number of anaerobic bacteria were isolated from the samples received from the Abdominal surgery. The overview of antimicrobial sensitivity showed highest sensitivity to metronidazole (99,9\%) and carbapenems $(99,9 \%)$, respectively.

Conclusions The most commonly isolated anaerobic bacteria was Bacteroides spp. Highest number of positive isolates was from abdominal surgery since intra-abdominal infections reflect the microflora of the resected organ. Metronidazole remains the antibiotic of choice in the treatment of anaerobic infections.
\end{abstract}

Keywords: anaerobic bacteria, wounds, resistance

\section{INTRODUCTION}

Anaerobic bacteria are a significant part of the normal microbiota colonizing skin and various mucosal surfaces of human body [1].They are recognized as opportunistic pathogens since infections most generally arise when anaerobic bacteria are introduced into areas of the body that are considered to be sterile [2]. Anaerobic bacterial infections are common and may be serious and life threatening [3]. Anaerobes are more commonly found in poly-microbial aerobic and anaerobic infections of endogenous origin [4]. Because of their fastidious nature they are difficult to isolate from infectious sites. Their isolation requires appropriate methods of collection transportation and cultivation of specimens [5-7].

Breach in mucosal barriers due to surgery, trauma, tumors, or ischemia lead to infections by these microbes following entry of endogenous flora into normally sterile sites [8]. Although anaerobic infections in the surgical patient are typically associated with procedures that involve the gastrointestinal tract, virtually any anatomic site can harbor anaerobic growth [9].Anaerobic infections occur in surgical patients in part because of structural or functional defects in the host that cause a breech in the normal mucosal barriers, create localized vascular insufficiencies, or produce an obstruction [9]. Since wound colonization is most 
frequently poly-microbial [10], involving numerous microorganisms that are potentially pathogenic, any wound is at some risk of becoming infected [11].

Wounds represent a suitable habitat for colonization of anaerobic bacteria, and their proliferation contributes to moist and warm environment, hypoxic and necrotic tissue, as well as the impairment of immune defence mechanisms [12]. Varying rates of anaerobic bacterial isolation have been reported across the globe from different clinical infection sites [13]. Anaerobes are the most overlooked microorganisms in many of the clinical specimens. Failure to identify them and provide antimicrobial coverage may result in therapeutic failure. Therefore, it is important to know the microbial pathogen responsible for the infectious process [1].

The aim of this study was to determine prevalence and susceptibility pattern of anaerobic bacteria isolated from wound swabs in Clinical centre University of Sarajevo.

\section{MATERIALS AND METHODS}

The study is retrospective and was conducted at Clinical centre University of Sarajevo over a period of three years from 1.1.2015 to 31.12.2017. The study involved wound swab samples, which were collected from patients admitted to various clinics of Clinical centre University of Sarajevo. Following the acquisition of wound swab for microbiological analysis, prompt delivery of the specimen to the laboratory is considered to be of outmost importance [14]. Microbiological testing of anaerobic bacteria in a wound sample included: macroscopic examination of the submitted sample, cultivating samples under anaerobic conditions, and VITEK 2 Compact system (bioMerieux, Marcy l'E toile, France) using VITEK ID ANC card. The specimens were processed for Gram stain and the anaerobic cultures were done on triptic soy agar with hemin and menadione. Antimicrobial susceptibility testing was done for metronidazole, imipenem, clindamycin and penicillin by disc diffusion test. The inoculated culture plates were incubated in anaerobic Gaspak jars (BD Diagnostics, Sparks, MD, USA) for $48 \mathrm{~h}$. The specimens were also cultured aerobically on $5 \%$ sheep blood agar and MacConkey agar with the addition of thioglycollate broth. Isolates were identified following standard methods [15]. Preliminary identification of the anaerobic isolates was done by colony morphology and Gram stain. Automated microbial identification systems, VITEK 2 (ANC card, bioMerieux, Marcy l'E toile, France) were used for species level identification.

\section{RESULTS}

A total of 8386 samples were received and examined in Microbiology department of Clinical centre University of Sarajevo. Pathogenic anaerobes $(n=1077)$ were isolated from 872 (10.4\%) samples. (Figure 1, Table 1) .

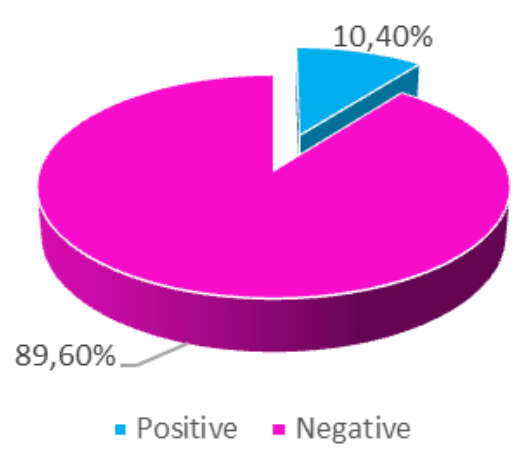

Figure 1. Positive and negative samples

Table 1. Number of positive samples

\begin{tabular}{|l|l|l|l|l|}
\hline $\begin{array}{l}\text { Number of } \\
\text { samples }\end{array}$ & 2245 & 3140 & 3001 & 8386 \\
\hline $\begin{array}{l}\text { Number } \\
\text { of positive } \\
\text { samples }\end{array}$ & 332 & 244 & 296 & 872 \\
\hline
\end{tabular}

Bacteroides spp. was the most commonly isolated anaerobic pathogens during three years, but its rate decreased from $55.5 \%$ in 2015 to $42,5 \%$ in 2017 (It was followed by Peptococcus spp.: 2015 - 17.1\%; 201613.9\%; 2017-17.4\%. Rate of Fusobacterium spp. in 2015, 2016 and 2017 was $11.9 \%, 11.1 \%$ and $11.9 \%$, respectively. Clostridium spp. was isolated in the highest rate during 2017: 9.2\%. (Table 2)

Table 2. Rate of isolated bacterial species

\begin{tabular}{|l|l|l|l|l|l|}
\hline & No & $\%$ & No & $\%$ & No \\
\hline $\begin{array}{l}\text { Bacteroides } \\
\text { spp. }\end{array}$ & 227 & 55.5 & 139 & 48 & 161 \\
\hline $\begin{array}{l}\text { Clostridium } \\
\text { spp. }\end{array}$ & 32 & 7.8 & 21 & 7.3 & 35 \\
\hline $\begin{array}{l}\text { Fusobacterium } \\
\text { spp. }\end{array}$ & 49 & 11.9 & 32 & 11.1 & 45 \\
\hline $\begin{array}{l}\text { Gram positive } \\
\text { nonsporogenic } \\
\text { anaerobic rods }\end{array}$ & 20 & 4.88 & 22 & 7.6 & 27 \\
\hline $\begin{array}{l}\text { Peptococcus } \\
\text { spp. }\end{array}$ & 70 & 17.1 & 40 & 13.9 & 66 \\
\hline $\begin{array}{l}\text { Other } \\
\text { Total }\end{array}$ & 11 & 2.7 & 35 & 12.1 & 45 \\
\hline
\end{tabular}

VITEK 2 Compact system (bioMe rieux, Marcy l'E toile, France) has identified from pure culture 48 isolates: Prevotella oralis 9 (18.8\%), Clostridium clostridioforme 7 (14.6\%), Clostridium group 7 (14.6\%), Prevotella melaninogenica 1 (2.1\%), Bacteroides fragilis 2 (4.1\%), Bacteroides group 2 (4.1\%), Peptostreptococcus anaerobius 1 (2.1\%), Peptoniphilus asaccharolyticus 1 (2.1\%), Fusocaterium nucleatum 2 (4.1\%). There was 17 (35.4\%) unidentified samples (Figure 2). 


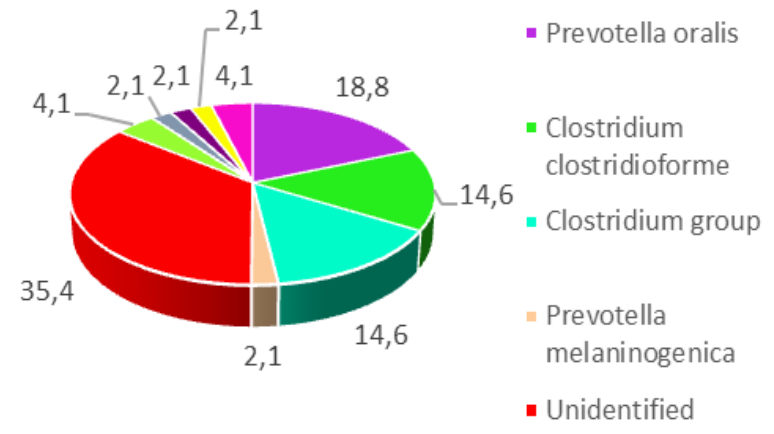

Figure 2. Rate of isolated bacterial species using VITEK 2 Compact system (bioMerieux)
Our study included 32 clinics. The largest number of positive isolates during three years was from the samples received from Abdominal surgery: 2015 19.3\%; 2016-17.6\%; 2017 - 16.9\%. Rate of positive samples isolated from specimens received from Orthopedic surgery decreased from 2015 (14.7\%) to 2017 (9.1\%). Also we recorded an increase of positive samples from Angiology: 2015-9.8\%; 2016-11,1\%; 2017$14.2 \%$ and Plastic surgery: 2015 - 6.3\%, $2016-13.9 \%$; $2017-16.9 \%$ (Table 3 ).

Table 3. Distribution of positive samples

\begin{tabular}{|c|c|c|c|c|c|}
\hline \multirow{3}{*}{ Angiology } & \multicolumn{2}{|l|}{2015} & \multicolumn{2}{|l|}{2016} & \multirow{2}{*}{$\begin{array}{l}2017 \\
\text { Number }\end{array}$} \\
\hline & Number & $\%$ & Number & $\%$ & \\
\hline & 34 & 9.8 & 27 & 11.1 & 42 \\
\hline ICU & 34 & 9.8 & 19 & $7 \cdot 7$ & 23 \\
\hline Abdominal surgery & 67 & $19 \cdot 3$ & 43 & 17.6 & 50 \\
\hline Orthopedic surgery & 51 & 14.7 & 15 & 6.1 & 27 \\
\hline Plastic surgery & 22 & 6.3 & 34 & 13.9 & 29 \\
\hline Gynecology & 8 & 2.3 & 10 & 4.1 & 8 \\
\hline Vascular surgery & 9 & 2.6 & 6 & 2.4 & 12 \\
\hline Nephrology & 9 & 2.6 & 7 & 2.9 & 17 \\
\hline Pediatric surgery & 15 & $4 \cdot 3$ & 2 & 0.8 & 8 \\
\hline
\end{tabular}

The overview of sensitivity and resistance to antibiotics showed the highest sensitivity to metronidazole (99.9\%) and carbapenems in all isolated anaerobic bacteria (Table 4 ).

Table 4. Overall resistance of anaerobic bacteria

\begin{tabular}{|l|l|l|l|l|}
\hline \multicolumn{1}{|c|}{ R } & No & $\%$ & No & $\%$ \\
\hline Penicillin & 736 & 71.1 & 299 & 28.9 \\
\hline Clindamycin & 388 & 41.1 & 558 & 58.9 \\
\hline Metronidazole & 2 & 0.1 & 1062 & 99.9 \\
\hline Carbapenems & 5 & 0.4 & 1080 & 99.6 \\
\hline
\end{tabular}

Resistance to clindamycin at Bacteroides spp. increased from 2015 (45.5\%) to 2017 (64.5\%). There was no resistance to metronidazole and carbapenems in 2016 and 2017 (Table 5).

Table 5. Overall resistance of Bacteroides spp

\begin{tabular}{|l|l|l|l|l|l|l|l|l|l|l|l|l|}
\hline & r & \% & S & S & \% & r & $\%$ & S & $\%$ & r & $\%$ & S \\
\hline Penicillin & 208 & 98.5 & 3 & 1.5 & 139 & 100 & 0 & 0 & 161 & 100 & 0 \\
\hline Clindamycin & 71 & 45.5 & 85 & 54.4 & 76 & 54.6 & 63 & 45.4 & 104 & 64.5 & 57 \\
\hline Metronidazole & 1 & 0,5 & 219 & 99.5 & 0 & 0 & 139 & 100 & 0 & 0 & 161 \\
\hline Carbapenems & 2 & 0,9 & 231 & 99,1 & 0 & 0 & 139 & 100 & 0 & 0 & 161 \\
\hline
\end{tabular}

Peptococus spp. showed the highest resistance to penicillin: 2015 - 42.9\%; $2016-40 \% ; 2017-43,9 \%$. Resistance to clindamycin increased from $2015(18.8 \%)$ to $2017(27.3 \%)$. There was no resistance to metronidazole and carbepenems in 2016 and 2017 (Table 6). 
Table 6. Overall resistance of Peptococcus spp

\begin{tabular}{|l|l|l|l|l|l|l|l|l|l|l|l|l|}
\hline & r & \% & S & \% & r & \% & S & $\%$ & r & $\%$ & S \\
\hline Penicillin & 27 & 42.9 & 36 & 57.1 & 16 & 40 & 24 & 60 & 29 & 43.9 & 37 \\
\hline Clindamycin & 9 & 18.8 & 39 & 81.3 & 11 & 27.5 & 29 & 72.5 & 18 & 27.3 & 48 \\
\hline Metronidazole & o & o & 67 & 100 & 0 & 0 & 40 & 100 & 0 & 0 & 66 \\
\hline Carbapenems & 1 & 1.4 & 70 & 99.6 & 0 & 0 & 40 & 100 & 0 & 0 & 66 \\
\hline
\end{tabular}

Clostridium spp. showed increase in resistance to penicillin: 2015 - 10\%; 2016- 23.8\%; 2017- 31.5\% and clindamycin: $2015-5.9 \% ; 2016-9.5 \% ; 2017-11.4 \%$. There was no resistance to metronidazole and carbepenems in 2016 and 2017 (Table 7).

Table 7. Overall resistance of Clostridium spp

\begin{tabular}{|l|l|l|l|l|l|l|l|l|l|l|l|}
\hline & r & \% & S & \% & r & $\%$ & S & $\%$ & r & $\%$ & S \\
\hline Penicillin & 3 & 10 & 27 & 90 & 5 & 23.8 & 16 & 76.2 & 11 & 31.5 & 24 \\
\hline Clindamycin & 1 & 5.9 & 16 & 94.1 & 2 & 9.5 & 19 & 90.5 & 4 & 11.4 & 31 \\
\hline Metronidazole & o & 0 & 32 & 100 & 0 & 0 & 21 & 100 & 0 & 0 & 35 \\
\hline Carbapenems & 1 & 3 & 32 & 97 & 0 & 0 & 21 & 100 & 0 & 0 & 35 \\
\hline
\end{tabular}

Fusobacterium spp. showed a decrease in resistance to clindamycin: 2015- 11.8\%; $2016-3.1 \%$; $2017-6.6 \%$. There was no resistance to metronidazole and carbepenems in 2016 and 2017 (Table 8).

Table 8. Overall resistance of Fusobacterium spp

\begin{tabular}{|c|c|c|c|c|c|c|c|c|c|c|c|}
\hline & \multicolumn{4}{|c|}{2015} & \multicolumn{4}{|c|}{2016} & \multicolumn{3}{|c|}{2017} \\
\hline & $\mathbf{r}$ & $\%$ & s & $\%$ & $\mathbf{r}$ & $\%$ & $\mathbf{s}$ & $\%$ & $\mathbf{r}$ & $\%$ & $\mathbf{s}$ \\
\hline Penicillin & 13 & 31 & 29 & 69 & 12 & $37 \cdot 5$ & 20 & 62.5 & 14 & 31.1 & 31 \\
\hline Clindamycin & 4 & 11.8 & 30 & 88.2 & 1 & 3.1 & 31 & 96.9 & 3 & 6.6 & 42 \\
\hline Metronidazole & 1 & 2.1 & 47 & $97 \cdot 9$ & o & o & 32 & 100 & o & o & 45 \\
\hline Carbapenems & 1 & 2 & 48 & 98 & o & o & 32 & 100 & o & o & 45 \\
\hline
\end{tabular}

\section{DISCUSSION}

Since wound colonization is most frequently polymicrobial [16], involving numerous microorganisms that are potentially pathogenic, any wound is at some risk of becoming infected.

The abundance and diversity of microorganisms in any wound will be influenced by factors such as wound type, depth, location, and quality, the level of tissue perfusion, and the antimicrobial efficacy of the host immune response [11]. We analysed 8386 samples, and pathogenic anaerobes were isolated in 872 (10.4\%) samples. Ercic et al. in their study which involved 367 samples have isolated anaerobes in 28 samples (7.6\%) [17], while De et al. have reported post-operative wounds and diabetic foot ulcers were infected with anaerobic bacteria in $30.1 \%$ of cases [18].

Successful isolation of anaerobes depends on specimen collection and transportation procedures, anaerobic incubation system and the quality and selection of the primary isolation media. For optimal recovery, it is necessary that specimens are transported within 30 minutes after collection and if anaerobic transport media are used, within 2-3 hours to the laboratory [19]. We found Bacteroides spp. is the predominantly isolated species, although there was a decrease in its rate from $2015(55.5 \%)$ to $2017(42.5 \%)$. Similar results with Bacteroides spp. as the most frequently isolated microorganisms from surgical infections have been reported by the others $[9,20]$. Kierzkowska et al. in their study isolated 1274 obligate anaerobes. Most frequently isolate was Bacteroides spp. (46.9\%) [21], and their result contemplate with ours. Second most commonly isolated strain was Peptococcus spp.: 2015 17.1\%; 2016-13.9\%; 2017-17.4\%). Peptococcus spp. along with Peptostreptococcus spp. is very common isolate in poly-microbial infections and infections of tissues and wounds [22]. A number of surveys have looked at the frequency of anaerobes in clinical specimens and found that gram positive anaerobic cocci constitute $24-31 \%$ of all anaerobic isolates [23-24]. 
The colonization of wounds often involves polymicrobial biofilm communities and populating bacteria often become resistant to many antibiotics. Numerous studies have reported the recovery and isolation of gram positive anaerobic cocci from both acute and chronic wounds [25].

Clostridium spp. had the highest rate during 2017 (9.2\%). Among the spore forming gram positive bacilli, Clostridium spp. was commonly found in association with diabetic foot infection (5.1\%) and $C$. perfringens (1.9\%) was isolated from six cases of gas gangrene [1].Clostridium spp. have also been reported to be predominantly isolated from wound infections, abscesses, abdominal infections, and blood [3, 26]. Fusobacterium spp. rate in 2015, 2016 and 2017 was $11.9 \%, 11.1 \%$ and $11.9 \%$ respectively. Brook reported that Fusobacterium spp. were most frequently recovered in post-surgical wounds in children proximal to the oral area [27].

VITEK 2 Compact system (bioMerieux, Marcy l'E toile, France) has identified from pure culture 48 isolates. Reason for the small number of identified isolates can be poly-microbial etiology of wound samples and in those situations is hard to obtain a pure culture needed for VITEK 2 Compact system (bioMerieux, Marcy l'E toile, France). Surgical infections are largely poly-microbial and both aerobic and anaerobic bacteria have been involved in the pathogenesis of these infections [11]. During three year period study, our results revealed that the largest number of anaerobic bacteria were isolated from samples received from abdominal surgery. Bacteroides species are normally commensals in the gut flora. When the Bacteroides organisms escape the gut, usually resulting from rupture of the gastrointestinal (GI) tract or intestinal surgery, they can cause significant pathology, including abscess formation in multiple body sites (e.g., the abdomen, brain, liver, pelvis, and lungs) as well as bacteremia [28].

Gorbach et al. have also shown that the major source of Clostridial infections could be intraabdominal sepsis associated with trauma or prior intestinal surgery [29]. Also our results revealed a decrease of positive samples received from Orthopedic surgery; from $14.7 \%$ to $9.1 \%$. Dhillon et al. in their study reported wound infection rates following orthopedic surgery are relatively low (2 to $6.8 \%$ ) [30]. There is an increase of positive samples received from Angiology from 9.8\% to $14.2 \%$. and Plastic surgery from $6.3 \%$ to $9.8 \%$. Patients that are treated on these clinics are usually diabetic patients with different ulcers and diabetic wounds. Also on plastic surgery all burn wound are treated.

Infection is a major complication in burn wounds, and it is estimated that up to $75 \%$ of deaths following burn injury are related to infection [31].

Some other studies showed that anaerobic bacteria have been shown to represent between 11 and 31\% of the total number of microbial isolates from burn wound [32].

The microflora of chronic venous leg ulcers is frequently poly-microbial, and anaerobes have been reported to constitute approximately $30 \%$ of the total number of isolates in non-infected wounds [33]. With good microbiological techniques, anaerobes have been isolated from up to $95 \%$ of diabetic wounds, the predominant isolates being Peptostreptococcus, Bacteroides, and Prevotella spp. [11].

Bacteroides spp. had the highest resistance rate on Penicillin (100\% in 2016 and 2017), which contemplates with the results of Novak et al. from 2013. Their study showed that Bacteroides spp. resistance on penicillin was $97.1 \%$, and on clindamycin was $29 \%$ [34].

Clostridium spp. resistance rates on penicillin and clindamycin are increasing in our study. Resistance on penicillin increased from $10 \%$ to $31.5 \%$ and to clindamycin from $5.9 \%$ to $11.4 \%$. Resistance rates of Bacteroides spp. and Peptococcus spp. on clindamycin are also increased, while at Fusobacterium spp. decreased from $11.8 \%$ to $6.6 \%$. Clindamycin was considered the gold standard for the treatment of anaerobic infections some $40-50$ years ago, but with the emergence of high levels of resistance among $C$. difficile $(\sim 70 \%)$, Bacteroides fragilis group (30-40\%), Prevotella spp. (10-40\%), other related anaerobic Gram-negative bacteria $(\sim 10 \%)$ and Peptostreptococcus spp. ( 10\%), this drug lost its significance as a first-line drug [35].

In 2016 and 2017 there was no resistance of anaerobic bacteria to metronidazole and carbapenems. The prevalence of resistant Gram-positive cocci and Gramnegatives on metronidazole is usually very low $(<1 \%)$ [36]

\section{CONCLUSION}

Anaerobic bacteria are common isolate in wound specimen. Successful management of wounds and their microbial flora depend on the performance of anaerobic cultures. Unless they are cultured and susceptibility tests are performed as a routine, true magnitude of antimicrobial resistance among anaerobic pathogens will not be known.

\section{SAŽETAK}

Uvod: Anaerobne bakterije mogu uzrokovati infekcije različitih dijelova ljudskog organizma. Mogu biti životno ugrožavajuće sa značajnom stopom morbiditeta i mortaliteta. Rane predstavljaju pogodnu sredinu za kolonizaciju anaerobim bakterijama i njihovoj proliferaciji značajno doprinose vlažno i toplo okruženje, hipoksična i nekrotična tkiva.

Metode: Retrospektivna studija je provedena u Kliničkom centru Univerziteta u Sarajevu u periodu 2015-2017 godina. Studija je obuhvatila uzorke briseva rana uzorkovane od hospitaliziranih pacijenata. 
Anaerobne bakterije su izolirane standardnim procedurama.

Rezultati: Tokom trogodišnjeg perioda (1.1.2015.31.12.2017.) analizirano je 8386 uzoraka, od kojih je 872 $(10,4 \%)$ bilo pozitivno na anaerobne bakterije. Tokom 2015 godine 332 (15\%) uzoraka je bilo pozitivno, dok je u 2016. i 2017. 244 (7.8\%) i 296 (9.9\%). Najčešće izolirana anaerobna bakterija tokom ispitivanog perioda je Bacteroides spp.: 2015. godine-227 (55.5\%); 2016. godine-139 (48\%); 2017. godine-161 (42.5\%). Izolirani su i Peptococcus spp.: 2015 godine-70 (17.1\%); 2016. godine -40 (13,9\%); 2017 godine-66 (17,4\%), Clostridium spp.: 2015. godine - 32 (7.8\%); 2016. godine-21 (7.3\%); 2017. godine- 35 (9.2\%), Fusobacterium spp.: 2015. godine - 49 (11.9\%); 2016. godine-32 (11.1\%); 2017. godine- 45 (11.9\%). VITEK 2 Compact je identificirao do nivoa speciesa 48 izolata u čistoj kulturi. Najveći broj anaerobnih bakterija je izoliran iz uzoraka sa Klinike za abdominalnu hirurgiju. Ispitivanjem antimikrobne osjetljivosti utvrđena je najveća osjetljivost na metronidazol (99.9\%) i karbapeneme (99.9\%).

Zaključak: Najčešće izolirana anaerobna bakterija je Bacteroides spp. Najveći broj pozitivnih izolata je sa Klinike za abdominalnu hirurgijju, jer intraabdominalne infekcije obično odražavaju mikrofloru reseciranog organa. Metronidazol ostaje antibiotik izbora u tretmanu anaerobnih infekcija.

Ključne riječi: anaerobne bakterije, rane, rezistencija

\section{REFERENCES}

1. Shenoy PA, Vishwanath S, Gawda A, Shetty S, Anegundi R, Varma M, Mukhopadhyay C, Chawla K. Anaerobic bacteria in clinical specimens-frequent, but a neglected lot: a five year experience at a tertiary care hospital. J Clin Diagnostic Res. 2017;11(7):DC44-C-DC48.

2. Wren M. An introduction to clinical anaerobic bacteriology. Don Whitley Sci Lim 2016; 1:256.

3. Kamble S, Pol S, Jose T, Gore V, Kagal A, Bharadwaj R. The prevalence of anaerobes from cutaneous and subcutaneous wound infections. Indian J Basic Appl Med Res 2014; 3: 371-378.

4. Cohen-Poradosu R, Kasper DL. Anaerobic Infections: General concepts. In: [3] Bennet JE, Dolin R, Blaser MJ eds. Mandell, Douglas and Bennett's principles and practice of infectious diseases. 8th ed. Philadelphia: Elsevier/ Saunders, 2015: 2736-2743.

5. Brook I. Anaerobic infections: diagnosis and management. Informa Healthcare USA, Inc, New York, NY. 2007.

6. Jousimies-Somer HR, Summanen P, Baron EJ, Citron DM, Wexler HM, Finegold SM. Wadsworth-KTL anaerobic bacteriology manual, 6th ed. Star Publishing, Belmont, CA. 2002.
7. Nagy E. Anaerobic infections: update on treatment considerations. Drugs 2010: 70: 841-858.

8. Finegold SM. Overview of clinically important anaerobes. Clin Infect Dis 1995; 20 (Suppl 2): S205-207.

9. Edmiston CE, Krepel JC, Seabrook RG, Jochimsen GW. Anaerobic Infections in the Surgical Patient: Microbial Etiology and Therapy. Clinical Infectious Diseases 2002; 35 (1): S112-S118.

10. Bowler P G. The anaerobic and aerobic microbiology of wounds: a review. Wounds. 1998;10:170-178], [Bowler P G, Davies B J. The microbiology of acute and chronic wounds. Wounds 1999; 11: 72-79.

11. Bowler P.G, Duerden B.I, Armstrong D.G. Wound Microbiology and Associated Approaches to Wound Management. Clin Microbiol Rev 2001; 14(2): 244-269.

12. Vraneš J, Drenjančević D. Antibiotička terapija kroničnih rana. Medix 2003; 9 (51): 45-48.

13. Garg R, Kaistha N, Gupta V, Chander J. Isolation, identification and antimicrobial susceptibility of anaerobic bacteria: a study re-emphasizing its role. J Clin Diagn Res 2014; 8(11): DLo1-DLo2.

14. Brook I. Collection and transportation of specimens in anaerobic infections. J Fam Pract 1982; 15: 775-779.

15. Collee JG, Miles RS, Watt B. Tests for identification of bacteria. In: Collee JG, Fraser AG, Marmion BP, Simmons A eds. Mackie and McCartney Practical Medical Microbiology. 14th ed. New York: Churchill Livingstone, 1996.

16. Mousa, H. A. 1997. Aerobic, anaerobic and fungal burn wound infections. J Hosp Infect. 37: 317-323.

17. Ercis S, Tunçkanat F, Hasçelik G. Anaerobic bacteria isolated from patinets with suspectd anaerobic infections. Microbiyol Bul 2005; 39(4): 447-454.

18. De A, Gogate A.Prevalence of gram negative anaerobic bacilli in routine clinical specimens. Indian J Pathol Microbiol 2001; 44(4): 435-438.

19. Mangels J. Anaerobic transport systems: are they necessary? Clin Micro News Letter 1994; 16(13): 101-104.

20. Saini S, Gupta N, Aparna Lokveer, Griwan MS. Surgical infections: A Microbiological study. Braz J Infect Dis 2004; 8:118-125.

21. Kierzkowska M, Majewska A, Kqdzielska J, Rozpara A, Sawicka-Grzelak A, Młynarczyk G. Participation of gram-negative anaerobes in infections in hospitalized patients. Med Dosw Mikrobiol 2011; 63(3): 235-240.

22. Gillespie S, Bamford K. Medical microbiology and infection. John wiley and Sons, Ltd. 2012:47-48. 
23. Boyanova LD, Vladimir G, Gergova I, Dragomir D, Petrov D, Osmanliev Z, Minchev Z, Mitov I. Anaerobic microbiology in 198 cases of pleural empyema: a Bulgarian study. Anaerobe 2004; 10: $261-267$.

24. Brazier JD, Chmelar L, Dubreuil G, Feierl M, Hedberg S, Kalenic E, Kononen B, LundgrenH, Malamou- Ladas E, Nagy A, Sullivan A \& Nord CE. European surveillance study on antimicrobial susceptibility of Gram- positive anaerobic cocci. Int $\mathrm{J}$ Antimicrob Agent 2008.31: 316-320.

25. Wall IB, Davies CE, Hill KE, Wilson MJ, Stephens P, Harding KG, Thomas DW. Potential role of anaerobic cocci in impaired human wound healing. Wound Repair Rege 2002; 10: 346-353

26. Brook I. Recovery of anaerobic bacteria from clinical specimens in 12 years at two military hospitals. J Clin Microbiol 1988; 26(6): 11811188.

27. Brook I Microbiology and menagemanet of post-surgical wound infections in children. Pediatr Rehabil 2002; 5(3): 171-176.

28. Wexler M.H. Bacteroides: the good, the Bad and the Nitty-Gritty. Clinical microbiology reviews 2007; 20(4): 593-621.

29. Gorbach SL, Thadepalli H. Isolation of Clostridium in human infections: evaluation of 114 cases. J Infect Dis 1975; 131: S81-85.

30. Dhillon, K. S., and C. S. Kok..The incidence of post-operative wound infection in orthopaedic surgery. Med J Malays 1995. 50: 237-240.

31. Vindenes, H., and R. Bjerknes. Microbial colonisation of large wounds. Burns 1995; 21: 575- 579 .

32. . Bariar, L. M., S. M. Vasenwala, A. Malik, G. H. Ansari, and T. E. Chowdhury. 1997. A clinicopathological study of infections in burn patients and importance of biopsy. J Indian Med Soc 95: 573-575.

33. Bowler PG and Davies BJ. The microbiology of infected and noninfected leg ulcers. Int J Dermatol 1999; 38:101-106.

34. NovakA, RubićZ, Dogas V, Goic-Barisic I, Radic M, Tonkic M. Antimicrobial susceptibility of clinically isolated anaerobic bacteria in a University Hospital Centre Spilt, Croatia in 2013. Anaerobe 2015; (31): 31-6.

35. Gajdács M, Spengler G, Urbá E. Identification and Antimicrobial Susceptibility Testing of Anaerobic Bacteria: Rubik's Cube of Clinical Microbiology?. Antibiotics 2017; 6: 25.

36. Lewis, K. Platforms for antibiotic discovery. Nat Rev Drug Discov 2013; 12: 371-387.
Scan this QR code with your mobile device for instant access to the current Issue of Acta Medica Saliniana

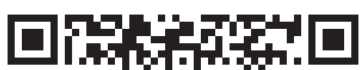

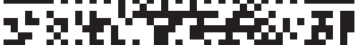

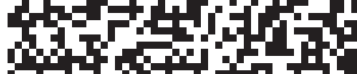

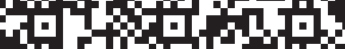
. .

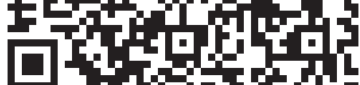

